Yasser K. Ragab.

Assistant Professor, English Department,

Or Al - Alsun, Minia University, Egypt.

The First International Conference of the

Faculty of Al-Alsun, Minia University

Egypt in World Litcrature

14 - 15 April 2004

\title{
Misrepresentation of the Arabs in the Western Media
}

For most Americans (the same is generally true for Europeans) the branch of the cultural apparatus that has been delivering Islam to them for the most part includes the tele-vision and radio networks, the daily newspapers, and the mass circulation news magazines; films play a role of course... Together, this powerful concentration of mass media can be said to constitute a communal core of interpretations providinga certain picture of Islam and, of course, reflecting powerful interests in the society served by the media. Along with this picture...goes what we may call its over-all context. By context I mean the picture's setting, its place in reality, the values implicit in it, and, not least, the kind of attitude it promotes in the beholder.Thus, if the Iranian crisis is regularly rendered by television pictures of chanting "Islamic" mobs accompanied by commentary about "Anti-Americanism," the distance, unfamiliarity, and threatening quality of the spectacle limit "Islam" to those characteristics; this in turn gives rise to a feeling that something basically unattractive and negative confronts us. Since Islam is "against" us and "out there," the necessity of adopting a confrontational response of our own towards it will not be doubted. (Said. Covering Islam. 48-9)

This research aims to investigate such biased misrepresentation of Muslims and Arabs by discussing and analyzing the motivating theories: the devil theory of Islam and the theory of conspiracy, which are dogged misguidedly by applying the one-dimensional perspective when Islâm and Arabs are concerned. Then it gives a critical analysis of three sample movies, viz., Not Without My Daughter, True Lies and Aladdin, and finally offers a possible solution.

Hollywood and the rest of American mass media have limited the spectacle so that they have represented nothing but disparaged Arabs whose tarnished negative images are recurrent in American motion pictures and television. More often than any other ethnic-religious group, Arabs and Musilims have been singled out as objects of prejudice, 
revulsion and despise-something evident in films such as Not Without My Daughter, True Lies and Aladdin.

Malicious representations of Muslims and Arabs are widely circulated in the American society presenting a demonic image of Islâm which has long obsessed the American mainstream thinking. However:

The absence in America either of a colonial past or of a long-standing cultural attention to Islam makes the current obsession all the more peculiar, more abstract, more secondhand. Very few

Americans, comparatively speaking, have actually had much to do with real Muslims (Said. Covering Islam. 13)

The article "Muslims in the West: Can Conflict Be Averted?" written in collaboration by Pipe and Duran highlights a remarkable increase of Muslims in the Western World. However Western media insists on depicting a negative image of so great a number instead of inculcating the idea of a wholesome hybrid society where there is still diversity within unity:

More than thirteen million Muslims, both immigrants and converts, live today in Western Europe and the United States. In Western Europe, Muslims number about twelve million. Over 3 million Muslims live in France, about 2 million in West Germany, $1 \frac{1}{2}$ million in the United Kingdom, and almost a million in Italy.

Half a million Muslims live in Belgium. Almost five centuries after the fall of Granada, Spain now hosts 200,000 Muslims. In many

West European countries Muslims have replaced Jews as the second largest religious community; they also outnumber Protestants and Jews in France, Catholics in Berlin, and so forth. In North America the numbers are much disputed, with a low of one million and a high of ten; the largest-scale study to date shows a Muslim population of 1.4 million. (Pipes and Durán )*

Not only has it grown a common and solid belief that Arabs are the West's default enemy but their image has also long been disfigured thanks to Western media and hired academics like Daniel Pipes, Khalid Durán ,Judith Miller, Martin Peretz, Lewis Bernard and many others. Stereotypical images of Arabs and Muslims are the creation of biased opinions which are basically patterned on two theories: the devil theory of Islâm and the conspiracy against Islam presented through the one dimensional representation of how those thinkers see the Muslim world. Said comments on the superficiality of the supposedly expert Orientalists: 
It is only a slight overstatement to say that Muslims and Arabs are essentially covered, discussed, and apprehended

* Whencver there is no pagination, this means it is a website. either as oil suppliers or as potential terrorists... What we have instead is a limited series of crude, essentialized caricatures of the Islamic world presented in such a way as, among other things, to make that world vulnerable to military aggression. (Said. Covering Islam. 28)

Indeed, Arabs are currently seen as terrorists and murderers according to the Western media. Mistrust and abhorrence have become American common feelings towards the distorted image of Arabs. The unconscious wish not to separate stereotypes from reality governs every aspect of Arab-Western relations. Arab movic stereotypes are wealthy, barbarians, uncultured, sex maniacs, terrorists and religious fanatics as in films such as Not Without My Daughter, True Lies and Aladdin. They are depicted as greedy who use oil, a natural and indispensable resource, to satisfy their hunger for money.

The word terrorism has unjustly become synonymous with the Arabs. In 1995 the Oklahoma City bombing was announced to be an act of terrorism done by Arabs, for which an inexplicable indictment $\mathrm{CNN}$ had provided names of Arab suspects even before facts were confirmedan act which reveals relentless prejudice. To the same effect Edward Said, in Covering Islam, writes:

Never was their prejudice and ignorance more in evidence than when in the immediate aftermath of the Oklahoma City bombing (April $1995)$ they leaped collectively to the conclusion-led by instant "experts" like Steven Emerson-that Islamic terror-ists were to blame, and they repeated their allegations, albeit on a smaller, quieter scale after the TWA Flight 800 disaster in July 1996. (35)

However, and to the American society's disappointment, it was an American citizen who had done it. Why do Western thinkers insist on misrepresentations of Muslims and the Arabs?

In his introduction to the Vintage edition (1997) of his book Covering Islâm, Said provides the answer to the above question:

Although I have discussed this elsewhere, it is important to insist that such claims about Islam and, most of the time, the Arabs, are designed to obscure what it is that Israel and the United States, as 
"Islam's" main opponents, have been doing.Between them the two countries have bombed and invaded several Islamic countries (Egypt, Jordan, Syria, Libya, Somalia, Iraq), they have, (in Israel's case) occupied Arab-Islamic territory in four countries, and in the United States' case are seen in the United Nations as openly supporting the military occupation of these territories; to the overwhelming majority of Muslims and Arabs, Israel is therefore an arrogant regional nuclear power, contemptuous of its neighbors, headless in the number and frequency of its bombings, killings (which far exceed the number of Israelis killed by Muslims), dispossessions and dislocations, especially so far as the Palestinians are concerned. (xxi)

Said does not mean that Muslims do not attack Israelis in the name of Islam. Rather, he objects to the fact that the media represents aggression as the nature of Islâm. Peretz, owner of The New Republic, has always been obsessed with Muslim-Arab hatred and "a relentless drive to defend Israel". He even "displaces on to the Muslims and Arabs a theory of gratuitous violence and cultural inferiority." ( See Said. Covering Islam. xxxii-iv). Another example of the worst offenders against Islâm is Bernard Lewis, once the senior British Orientalist and now a retired Princeton Professor. Throughout his work, which has mainly been published in The New York Review of Books, Commentary, Atlantic Monthly, and Foreign Affairs, he portrays "the whole of Islam as basically outside the known, familiar, acceptable world that "we" inhabit, and in addition that contemporary Islam has inherited European antiSemitism for use in an alleged war against-modernity." (See: Said. Covering Islam. $x$ xix- $\mathrm{x}$ )

Lewis's numerous essays on Islâm have indeed helped to widely circulate negative images about the Arabs and Muslims. However, the most offensive of all is "The Roots of Muslim Rage", published in the September issue of The Atlantic. Said sees it as a sordid attempt at dehumanizing Muslims: "The Roots of Muslim Rage" is a crude polemic devoid of historical truth, rational argument, or human wisdom. It attempts to characterize Muslims as one terrifyingly collectiveperson enraged at an outside world that has disturbed his almost primeval calm and unchallenged rule.(Said. Covering Islam. xxxii)

Such misrepresentations have more or less revived the old Orientalist thesis, since they divide the world into Orient and Occident-an act which has led to a number of momentous consequences: 
One is that a specific picture-for it is that- of Islam has been supplied. Another is that its meaning or message has on the whole continued to be circumscribed and stereotyped. A third is that a confrontational political situation has been created, pitting "us" against "Islam." A fourth is that this reductive image of Islam has had ascertainable results in the world of Islam itself. A fifth is that both the media's Islam and the culsural attitude to it can tell us a great deal not only about "Islam" but about institutions in the culture, the politics of information and knowledge, and national policy. (Said. Covering Islam. 44)

The misrepresentation of the Arabs is based on a sociopolitical negative image of a substitute devil for the Soviet Union, viz., Islâm. In a book review entitled "A Devil theory of Islam", Edward Said debunks Judith Miller's real intentions behind her book: God Has Ninety-Nine Names: A Reporter's Journey Through a Militant Middle East( Simon and Schuster, 1996):

"The search for a post-Soviet foreign devil has come to rest, as it did beginning in the eighth century for European Christendom, on Islam, a religion whose physical proximity and unstilled challenge to the West seem as diabolical and violent now as they did then. Never mind that most Islamic countries today are too poverty-stricken, tyrannical and hopelessly inept militarily as well as scientifically to be much of a threat to anyone except their own citizens; and never mind that the most powerful of them -- like Saudi Arabia, Egypt, Jordan and Pakistan s- are totally within the U.S. orbit. What matters to "experts" like Miller, Samuel Huntington, Martin Kramer, Bernard Lewis, Daniel Pipes, Steven Emerson and Barry Rubin, plus a whole battery of Israeli academics, is to make sure that the "threat" is kept before our eyes, the better to excoriate Islam for terror, despotism and violence, while assuring themselves profitable consultancies, frequent TV appearances and book contracts. The Islamic threat is made to seem disproportionately fearsome, lending support to the thesis (which is an interesting parallel to anti-Semitic paranoia) that there is a worldwide conspiracy behind every explosion." (Said. "A Devil Theory of Islam")

Said points out that the dramatization of Muslim threat to the West is nothing but a camouflage, a counter propaganda with which the West and Israel are familiar:

Arab Muslims today are too discouraged and humiliated, and also too anesthetized by uncertainty and their incompetent and crude dictatorships, to support anything like a vast Islamic campaign against the 
West. Besides, the elites are for the most part in cahoots with the regimes, supporting martial law and other extralegal measures against "extremists." So why, then, the accents of alarm and fear in most discussions of Islam? Of course there have been suicide bombings and outrageous acts of terrorism, but have they accomplished anything except to strengthen the hand of Israel and the United States and their client regimes in the Muslim world?

(Said. "A Devil Theory of Islam")

The discrepancy between the reality of the Muslim world and the fake appearance concocted by hired academics stresses Westerners' bigoted as well as chauvinistic tendencies when dealing with the Arabs and Islâm. Their breathtaking hunt for a scapegoat ultimately culminates into an unconscious self-induced indictment.

Miller's technique of overlooking facts in her book renders the diabolic image of Muslims groundless. Said makes it clear that she fanatically sides with Israel in her book:

She records Mohammed's depredations against the Jews but has little to say about Israeli beliefs, statements and laws against "non-Jews," often rabbinically sanctioned practices of deportation, killing,house demolition, land confiscation, annexation and what Sara Roy has called systematic economic de-development. If in her breathlessly excitable way Miller sprinkles around a few of these facts, nowhere does she accord them the weight and influence as causes of Islamist passion that they undoubtedly have.

\section{(Said. "A Devil Theory of Islam"))}

Taking Miller for what she really is, an exemplary bigot and chauvinist, Said sets a measure against which all polemicists can be measured:

Perhaps Miller's most consistent failing as a journalist is that she only makes connections and offers analyses of matters that suit her thesis about the militant, hateful quality of the Arab world. I have little quarrel with the general view that the Arab world is in a dreadful state, and have said so repeatedly for the past three decades. But she barely

registers the existence of a determined anti-Arab and anti-Islamic U.S. policy. She plays fast and loose with fact. (Said. "A Devil Theory of Islam")

Miller even falsifies some facts and overlooks others so long as it serves her search which obviously aims to create two antithetical images: one of devilish Arabs and backward Muslims and the other of tolerant Jews and developed West. Said delineates her plan: 
Miller cites instances of Arab anti-Semitism but doesn't even touch on the matter of Israeli leaders like Begin, Shamir, Eitan and, more recently, Ehud Barak (idolized by Amy Wilentz in The New Yorker) referring to Palestinians as two-legged beasts, grasshoppers, · cockroaches and mosquitoes. These leaders have used planes and tanks to treat Palestinians accordingly. As for the facts of Israel's wars against civilians -- the protracted, consistent and systematic campaign against prisoners of war and refugee camp dwellers, the village destructions and bombings of hospitals and schools, the deliberate creation of hundreds of thousands of refugees-all these are buried in reams of prattle. Miller disdains facts; she prefers quoting interminable talk as a way of turning Arabs into deserving victims of Isracli terror and U.S. support of it. She perfectly exemplifies The New York Times's current Middle East coverage, now at its lowest ebb.

(Said. "A Devil Theory of Islam)

In their lengthy article mentioned above, Pipes and Durán harp on the stereotypical image of the delault enemy by portraying Islamism \& Westernism as conflicting powersislamism calls for close adherence to the sacred law of Islam (the Shari'a), the voluminous set of laws formulated over a millennium ago which structures private and public life. This code regulates everything from ways to sneeze or yawn to the proper methods of concluding a business deal or waging war. Islamism attributes past glories to the Muslims' close adherence to the ancient law of Islam, recalling the Muslim wealth, power, and cultural achievement of the premodem period. God was in His place and society revolved around His commands. Westerners resented the medieval Muslim achievement and determined to destroy it; they did so in two ways, through military conquest and cultural infiltration. For Islamists, Western civilization represents the most profound threat facing Islam. (Pipes and Duran)

The authors try to promote detracting views about Islâm. Throughout their article they tend to unjustified malicious generalizations All quoted below do not, as a matter of course, represent the whole Muslim nation, of which fact they do not take a blind bit of notice:

Evidence suggests that the Islamist leadership does not reflect the true views of Western Muslim communities. For example, Algerian institutions in France which receive no funding from Muslim governments-community organizations, broadcasting stations, and the like-take a staunchly anii-Islamist position. Turkish community associations in Hamburg and Hannover have taken a firm stand 
against Islamist extremism. Muliammad Salim Abdullalı-German convert, former journalist with Radio Deutsclie Welle, publisher of the Moslemische Revue, a chronicler of inter-religious dialogue-has publicly decried the Islamists as "a menace." In 1990. Helga Ehlers, a Cologne journalist, conducted an inquiry with regard to the popularity of four prominent Muslims in Germany and found that the one most critical of Islamism fared best in the evaluation.

(Pipes and Durán)

The writers, though one of them apparently has an Arab name, Khalid, seem to be totally ignorant of the Islamic Shậriah, since they polemically misunderstand and devaluate the religious structure of the Islamic society:

Applying the Shari'a would permit men to effect divorce at will, keep the children, and deprive divorced women of alimony. It would also sanction polygamy for men. This raises a further question: if Muslims are subject to Islamic family laws, why not also their own penal laws, including the cutting of thieves' hands and the stoning of adulterers?

(Pipes and Durán)

That Muslims do not apply Islamic laws, which the authors ignorantly and fervently try to highlight, is not because of a dislike of their Shâriah. Rather, it is because their penal laws should, according to Shâriah, be executed accordingly. For example hand amputation is not applicable to first-time thieves or in time of famine. Stoning adulterers is for married people only. Singles are whipped for a hundred times in public.

Obviously they, like many others, fabricate the image of the devilish Islam through providing stereotypes on weak grounds:

Culturally the Islamists remain outsiders, getting to know just low culture and street culture, and even those superficially. While this picture is hardly unique (Chinatowns from Amsterdam to San Francisco share it), Muslim communities do have a special quality; they alone have a profoundly anti-Western ideology to fall back on. No immigrant group has an institution to parallel the Islamist mosques which teach that the West is evil, Westerners unclean and unworthy-old, somewhat abstract doctrines which acquire new tangibility when Muslims live in Europe or America. The xenophobia of Europeans and the racism of Americans take on explosive qualities once made to fit into this frame of reference.

(Pipes and Durán)

They show a strong misunderstanding of Islâm's view of secularism. They depict an image of backward Muslims and a futile 
religion due to their apparent ignorance. Their misconception is in fact one deeply rooted in misunderstanding of the Arabic language in which Islamic teaching is originally communicated. They recapitulate the notion of secularism in an incorrect translation of "ق"مهرة البطن و الفر ج" as "lust of the belly and vagina". The Arabic phrase, which means "the lust of the belly and sex", refers to the wocbegone imbalance that may occur to human beings if physical needs get the best of man:

But Islamists particularly fear secularism, which they interpret as the source of the West's evil (Muhammad Al-Bahiy, an Egyptian scholar and religious official, once likened secularism to the "lust of the belly and the vagina") and its chicf instrument to sap Islam of vitality. This obsession leads to strange assertions, such as the claim that the U.S Agency for International Development dispenses funds to Islamic educational institutions on the stipulation that these teach secularism. A Khomeinist correspondent wrote from London that "the remains of Muslim dead should be treated with respect and dignity ... without needlessly being subjected to the degrading rituals of secularism." These are not the rantings of isolated individuals but the ideology of a movement. (Pipes and Durán)

Although the authors keep in attacking Islâm, they unwittingly mention the truth, viz., "Some gangs have taken up Islâm as a cover for their criminal activities" (Pipes and Duran). They pass general judgments on the basis of single cases which can be found in any religion and done by any ethnic group. They fanatically say:

On arrival in the West, Middle Eastern and African immigrants tended to specialize in one or another type of criminal activity. In the 1960s and 1970s, Eastern Arabs established the notorious "Mercedes Route," transferring stolen cars from Western Europe to the Persian Gulf via Spain and North Africa. They also recruited-and sometimes even abducted-womien for prostitution in the Middle East, the socalled whire slave trade. Both these trades then declined; the police took sterner action when car thefts got out of hand, while

South and East Asian women took the place of European females.

(Pipes and Durán)

Then their bigotry goes so far that they try to tarnish Islâm, inculcating a wrong idea that Muslims are born thieves and frauds. In so doing they tacitly try to create a new concept of self-effacement, which is terrible in its sociopolitical repercussions: 
If Muslims have made their mark in criminal activity, it is in big business. Apart from the Paris-based Agha Khan, virtually every Muslim tycoon in the West has ended up prosecuted on account of fraud. 'Adnan Khashoggi and Ghaith Pharaon have been indicted in the United States, Rifat Sayed in Sweden, and Asil Nadir in Britain. (Nadir is now a fugitive from justice, hiding in Turkish Cyprus.) The less famous also have a way of getting in trouble. Muhammad Naviede, the owner of a trade finance company, Arrows Ltd, went into liquidation in August 1991 because of problems with the law. These major frauds have harmed the Muslim community's morale, held back its economic progress, and much damaged the unfolding of Islam in the West.

\section{(Pipes and Durán)}

However, in the introduction to the Vintage edition (1997) of his book Covering Islam, Said debunks real intentions of those journalists and thinkers whose aim is to make extravagant statements and foster into the readers' beliefs a distorted idea of Islâm being the same thing as fundamentalism. Pipes, a well known anti-Muslim Orientalist, is criticized for his superficiality and unreliability:

Or consider Daniel Pipes, a perfervid anti-Muslim whose main characteristic is that as an Orientalist he "knows" Islam for the appallingly dreadful thing that it is. He delivers himself of some reflections in a "think" piece published in the Fall 1995 issue of

The National Interest under the modest title "There are No Mode rates: Dealing with Fundamentalist Islam." Nowhere in the piece does he absolve radical radical Islam - which he does not bother to define, but which his title let's us assume is the same as the nonradical variety - of its real nature which, he tells us right off, is "closer in spirit to other such movements (communism, fascism) than to traditional religion.". .. Pipes's "fundamentalist" Islam

threatens the world, and especially "us," even though, according to State Department figures, terrorism originating in the Middle East is sixth in order of occurrence and frequency.

(Said. xviii-ix )

Pipes and Durán discussed the Muslim women rights from a nonIslamic perspective. They exerted great efforts to convince the reader of the unpardonable crimes committed against Muslim women and the social and psychological perdition they suffer from because of the application of Islamic rules. Worse still they only gave bad examples of 
personal behaviour which can not be taken as representative of the whole community:

Thousands of Muslim girls run away from the severity of their homes to find shelter with government agencies or pimps. More than a hundred cases of suicide or attempted suicide add urgency to the problem. Fathers and brothers sometimes abduct Muslim girls from school or social welfare agencies to ship them home and marry them off by force. They have sometimes resorted to murdering the

recalcitrant daughter or sister. (Pipes and Durán)

Contrary to this biased opinion, it is in the Western society that sexual relations and many vices, under the pretext of personal freedom, have long been allowed and approved. Therefore, it can easily be argued that those few examples quoted by the authors are affected by the Western environment. It seems that the authors do not have an idea that the Western society is marked by the highest rate of suicidal attempts due to lack of religion-in this respect Sweden can serve as a perfect example. Moreover, the authors' knowledge of women's status in Islam is unreliable. A comparison between the Western woman and her Muslim counterpart makes things clear. The entity and identity of the former was much argued by philosophers and scientists. Then came the industrial revolution which tore the family and changed long standing social conditions. The woman worked beside the man but was not equally paid. The World War I caused women to greatly outnumber surviving men. Bearing in mind that they refused polygamy and there were no breadwinners, the woman had to satisfy her physical needs. (See: Quryshi $6=10)$

On the contrary, the Muslim woman's equality to men was primarily accredited in the Qurân: "Oh, people! Be pious to Allah Who created you from one soul from which He created her spouse and from both many men and women were created." ( An Nisâ.1) Both men and women have the same rights: "Men have a share to inherit in what parents and relatives left and so do women."( An Nisâ.7). Moreover, both will be equally questioned on Doomsday: " God responded to them: I do not waste your deeds whether male's or female's as you have the same origin." (Al- Imrân195)

For more than twelve centuries, the European woman did not get the same rights which Islâm gave to her Muslim counterpart. Islâm has given the Muslim woman the right to choose and approve of her suitor, to join the army, to learn and participate in the society. Prophet Muhammad said that: "Every Muslim must seek education". The word "Muslim" refers to both men and women. (See AL Ashqar 42). The Prophet was 
keen on educating women. He urged his wives to learn how to read and write. ( See: Quryshi.20-1) Pipes and Durán unconsciously provide the clue to the enigmatic situation of Muslims in the Western society. The devil theory of Islâm they, and many others formulate, is the chief catalyst in the process of showing anti-Islamic sentiments. They maintain that:

Nativists stress the incompatibility of Islam with Western constitutionalism. They see a fundamentalist Islamic totalitarianism gaining in strength just as the communist version is losing its vigor. Economically, Muslim minorities are a liability who contribute more to overpopulation and unemployment than to productivity. Muslim invariably seek to impose their value system and lifestyle on others; where this advance meets with opposition, they resort to terrorism. Generations born in the West lack ties to their families' countries of origin, and so become deracinated and violence-prone.

(Pipes and Durán)

The naked truth is that it is the religion of Islâm, not Muslims, which is hated. Ironically enough, the Western world calls itself the guardian of freedom! The authors try to justify this kind of inexplicable hatred by giving it a historical dimension:

The fact of being Muslim is in and of itself a reason for antipathy. The historic anti-Islamic legacy of the Christian world causes Muslims to be more disliked than most foreigners (perhaps not more than the Vietnamese in Eastern Europe). Africans and Black Americans may suffer more by virtue of being more conspicuous, bat prejudices against them are actually less than those against Arabs, Turks and Pakistanis.

As Judith Miller noted with reference to Western Europe, "for the most part, non-Arab Africans are neither feared nor despised." Similarly,a French magazine noted that "Everyone talks of the problem of immigrants when in truth they have in mind just one category ... the Arabs." In sum, as Le Monde puts it, Europeans are convinced that Islam is not "a religion like the others."

(Pipes and Durán)

The authors insist on unfairly finding faults with Islâm by giving odd examples that distort the image of Arabs and Islâm:

Then there's the other level altogether, the world of Saudi playboys who flaunt their money and their lasciviousness. While small in number, the fame of their antics (such shopping sprees in London or painting the genitalia on statues in Beverly Hills) inspire considerable illwill. Here's the sort of scene, in an American hotel witnessed by an 
American doctor: "I was ushered into the living quarters set aside for the princes. It had the atmosphere of a bordello. Loud music was blaring from all directions, and white-coated waiters were running back and forth, carrying trays of assorted drinks and snacks.

The young princes and their friends were shouting to each other through the walls. There was loud, raucous laughter coming from the rooms, punctuated at times by a female scream. Semi-clad women could be seen darting from room to room, giggling, followed by Saudi princes who were unshaven and disheveled. Everyone seemed drunk to the gills. It looked as though the bacchanal had been going for some time".

(Pipes and Durán)

To tell the truth, detractors like Miller, Pipes and Durán are encouraged by Arabs' contemporary circumstances which they have partly created. In a review, entitled "Thwarted Dreams, of Fouad Ajami's book The Dream Palace of the Arabs: A Generation's Odyssey, published by Pantheon Books, New York, 1998, M.H. Ansari recapitulates the contemporary situation of the Arabs:

When it comes to the Arabs, it is fashionable to deride them.

The Arab becomes synonymous with the Islamic, which in turn is read today as extremist and anti-modern. The logical fallacy of the undivided middle is freely indulged in, a broad brush is used indiscrimi-nately, tools of intellectual scrutiny are put aside, contemporary history is ignored, the joys and pains of the people of a whole region are forgotten and media stereotypes, subconsciously reinforced by prejudices of one kind or the other, are imbibed as gospel truths. (Ansari)

The ills of the Arab nation, namely ignorance, hypocrisy, and stagnation, have fostered a crippling inability which results into failure when they attempt reform or approach modernity. This helps stress the negative image of Arabs and Islam. Therefore intellectual dialogues should be conduct with the aim of redressing our image. In reference to the faltering history of the Arabs' international self-representation, Ansari quotes a Kuwaiti academic whose words create an image of overlapping hope and despair:

The march of events, and an Arab's despondency over them, is exemplified in the words of a Kuwaiti academic: "I cheered in 1956, I cried in 1967 after the Six Day War. I cheered again

in 1973 when I was told that a new world beckoned the Arabs. Now in the summer of 1982, after a decade which began with

such promises closes with a bitter taste, I am too shocked for words, for tears or even for anger" (page 123). It was this frustration, this resignation, which induced the enthusiasticpublic response to the 
Palestinian Intifada of 1987, reflected so forcefully by Nazar Qabbani in his poem "Children of the Stones". (Ansari)

Despite depressed Arab voices, some Western writers give the Arabs and Islam due attention. In his article "Cultural factors in ArabWest Relations" Li Weijian , criticizing the devil theory made up by West detractors, writes:

The integration of their traditional culture with foreign cultures is of key importance to Arab modernization. The contemporary Islamic movement is fundamentally an inward social reform. Islamic culture has the trait of integrating and assimilating fine cultures of other nations. The so-called "Islamic threat" is actually a "Devil" fabricated by the West.

(Weijian)

It is undeniable that while Europe was still in its dark ages in science and culture, Islam had already reached the peak of human welfare. Great worldwide contributions in literature, philosophy, arts and science had been made by Islam. However the west's occupation of the Arab world led to nothing but backwardness.

In order to establish international cultural hegemony, as indeed Said criticized in his book Orientalism published in 1978, the West has always belittled Arab culture and undervalued it as the opposite of Western civilization. Against such a threat, the Arabs should show resistance as well as revive their cultural identity. In so doing, they will be eclectic in what they embrace from Western culture. To this effect, Weijian quotes Abd al-Aziz al-Duri who points out:

the Arab contact with the West, first as a culture and then as an imperialist power, was very important in clarifying the historical roots of Arab nation, in consolidating these roots, and in establishing their true implication. The Arabs welcomed the implications of freedom and tried to imitate the West in bettering their way of life and their economy. But they were not prepared to forsake their heritage or deny their identity. They took troubles for not losing this heritage and identity and did their best to emphasize these [national] characteristics.

(Weijian)

The clash between the West and the Arabs is a cultural one. Since the emergence of Islâm whose culture covered political, economic, social, literary and many other fields of life, the conflict between the West and Islâm has always been there. Throughout the stages of this struggle the Muslim nation has been suffering ups and downs. However, never have 
the Arab people succumbed to deadening depression. Rather, they turn to Islâm to get more stamina to resist. Weijian Supports the same idea:

The contemporary Islamic revival is fundamentally an inward social reform. This can be demonstrated by the background of the origin of Islamic revival and its internal and external reasons. The background of this movement lies in the Arab countries' disastrous and disgraceful defeat, loss of territory and complete discrediting in the third Middle East War; and the economic difficulties in most Arab countries, unjust distribution and a series of severe social problems such as corruption. The secular governments led by the nationalists were neither able to defeat Israel's invasion nor able to solve economic problems and achieve social justice and common prosperity. When this caused disappointment and pain among Muslims in those countries they turned to Islam for a way out. (Weijian)

The Muslimrevival does not aim to terrify people; however, it works for internal social, political and economic reform. On the other hand, it opposes external domination and intervention, exploiting natural wealth and destroying national culture. Therefore individual terrorist acts against Western countries should by no means be considered a representation of the whole Muslim nation. The Arabs historical contributions to world culture stress the important role they played in civilizing humanity at a time when Europe was immersed deep in ignorance and backwardness:

As we all know, Arabs began to introduce foreign cultures from the Umayyad Dynasty and reached its peak in Abbassid Dynasty, symbolized by the famous "translation movement". During this period of time, it widely absorbed the cultural quintessence of India, Persia, Greece, China, etc. For example, in philosophy, Arabs not only did a very good job in inheriting the color of Aristotle's school, but also integrated the theories of Hippocrates, Plato and Aristotle into Arab thought and spread them to the Latin world. All these produced a decisive influence on European philosophical studies during the Middle Ages and enabled Arab culture to bloom in the garden of world cultures. It is no exaggeration to say that if Arabs had not spread to West Europe the academic works of India, the papermaking technology of China, and the ancient Greek academic works lost in Europe, thereby preparing for the European Enlightenment and Renaissance, the brilliant history of the Renaissance in Europe would not have been written. Arabs made distinguished contributions to world culture in the Middle Ages while 
absorbing the quintessence of all kinds of cultures all over the world and enriching the content of the Islamic culture. (WEIJIAN)

To give the devil his due, the Muslim nation should be deservedly portrayed as a good example to follow. However, Hollywood keeps on portraying undeserved negative and stereotypical images of Arabs as seen in films such as "Not Without My Daughter", "True Lies" and "Aladdin".

Though negative stereotypes and mistaken representations of almost every minority in the world have been depicted in the movies, the Arab culture has been misunderstood to the extent that it has always been supplied with the worst stereotypes. Misrepresentation of the Arabs as thieves, charlatans, savages and murderers is illustrated in two films of the silent movie era1920s, viz., "The Sheik"(1921) and "Son of the Sheik" (1926) The image of the villain Arab versus the good Western man is highlighited in films such as "The Song of Love" (1923), "A Café in Cairo"(1924) and "The Desert Bride" (1928). However, "A Son of the Sahara" (1924) stresses racial love. Raoul, brought up by an Arabian desert tribe, falls in love with Barbara, An officer's daughter. His love is rejected because of his origin; however, when it is revealed that he is not Arab she falls in love with him. (Simon)

The twentieth century stresses negative images of Arabs as terrorists. "The Wind and the Lion" (1975) revolves around the kidnapping of an American woman by an Arab.

The makers of the film claimed that it was based on an historical account of an actual kidnapping case. However, the real 1904 kidnapping victim was a man, not a woman. Hollywood's alteration not only provided the intended effect of added excitement, but it also put an unwarranted label on the Arab community as being a group of terrorists fearful of confronting anyone more powerful than a woman. Further, while the negative theme of the Arab actions in the film did little to promote acceptance of Arabs in the world community, the casting of Sean Connery as the Arab terrorist further alienated the Arab community by implying that Arabs are not even worthy of portraying themselves in cinema. (Simon) 
"Black Sunday" (1977) portrays an Arab terrorist who wants to bomb the stadium and all its occupants, including the President of the United States. "Raiders of the Lost Ark" depicts a scimitar-wielding Arab who is in league with the Nazis.

The anti-Arab image on entertainment manifests itself in the politics of America. It accounts for the biased opinion that the villain of choice today is the ridiculed and despised Arab. The Arabic word "Allâh", which is the exact translation of "God", is used in American movies cynically. However, not only do Arab Muslims but Arab Christians and Jews also use it. To add a disparaging dimension to the negative image of the Arabs, American movies often portray them as Negroes. Though terrorist acts are done by many a nationality, they are blamed on Arabs, thanks to Hollywood. To this effect Sindi writes:

In his detailed study, The TV Arab, ArabAliierican scholar Jack G. Shaheen- professor emeritus of broadcast journalism at Southern Illinois University-documents pervasive negative imagery of Arabs by all American television networks, and by practically all leading newscasters and personalities working for them...Dr. Shaheen examined more than 100 popular television programs, totaling nearly 200 episodes, and interviewed numerous television executives, producers, and writers. American television, concludes Dr. Shaheenincluding popular entertainment, comedy, drama, documentaries, news, and even sports and religious and children's broadcastingacross the board has, at one time or another, presented distorted and demeaning images of Arabs.(Sindi)

However some of those who work in the cinema field disapprove of the negative images of Arabs:

Donn O'Brien, CBS vice president of broadcast standards, sheepishly admitted to Shaheen that he had never seen a "good Arab" on American television, and that Arabs are routinely presented as covetous desert rulers or as warmongers. "Arabs are rarely portrayed as good guys," 
acknowledged Frank Glicksman, a Jewish-American TV producer in Los Angeles. "I've never seen them portrayed as anything but heavies in melodrama. That, I feel, is unfair." Another Hollywood television producer, Don Brinkley, conceded: "The depiction of the Arab on television is generally horrendous." And George Watson, vice president of $\mathrm{ABC}$ News, admitted: "Arabs have not been seen to be as real, as close, or as tangible, eitleer as individuals or as a group, as the Israelis ..." (Sindi)

The above-mentioned negative images show themselves in "Not Without My Daughter", "True Lies" and "Aladdin". "Not Without My Daughter" revolves around an Iranian man who works as a doctor in the United States and has been married to an American woman for seven years. He decideù to return home with his wife and his daughter after the Islamic Revolution in Iran. Since he knew that she would never accept the idea of moving to Iran, he was forced to lie to his wife and tell her that his sister was sick and she wanted to see him, so they had to visit Iran for two weeks. After arrival, he told her that they would stay in Iran forever. Throughout the film, the American woman was trying to escape with her daughter to her country.

A clash of two different cultures is depicted: the "Islamic culture" represented by the portrayal of Iran, and the "Western calture" which the scenes in the United States stand for. In fact, the analysis of the film depends on the conspiracy theory as it is one of numerous attempts to give a bad image of Islâm and the Middle East. There is exaggeration in the way Islam is presented. Pipes and Durán voice the same biased opinion which the film is based on: injustice done to the Western woman who marries an Arab Muslim:

divorce leads to monumental fights over children. Western laws favor the mother, Islamic law awards children to the father. Herein lies many a vicious battle over custody. To preempt the process in an unfriendly court, Muslim fathers regularly abduct the children to their country of origin, far beyond the reach of Western laws. The men see themselves exercising a traditional prerogative; in addition, they take the children back to be raised in a traditional

setting and to save them from becoming street Arabs in the West. (Durán) 
To justify their attack on Islamic rules and to raise bigoted objections, the authors who overlook many attempts of abduction done by Western women, who have dwelt in the Arab region with their Arab husbands, dramatize and politicize the issue of interinarriage children:

In this context, the autobiographical story of Betty Mahmoody, an American citizen married to an Iranian, had enormous importance. Mahmoody's husband lured her to Iran, then refused to let her or their daughter return home. To hold the two, he locked them in an apartment for long stretches of time. Malumoody's 1987 book, Not Without My Daughter, dwells on her travails in Iran and her eventual escape. It received minimal attention in the United States until Hollywood produced a film starring Sally Field, finally becoming a best seller during the war with Iraq. Even then it sparked no discussion or controversy. In Europe, Not Without My Daughter resonated far more, becoming an immediate and much-discussed best-seller in Spain, France, Germany and Scandinavia. The German version, Nicht ohne meine Tochter, sold more than 4 million copies by 1993. It became fashionable for concerned friends to present a copy by way of warning to European women married to Iranians. In some cases, these women received 20 copies as gifts.(Pipes and Durán)

In fact, the film tries to create illogical differences between the two worlds of the Iranian husband and the American woman to the extent that one may wonder how they have been ever living together even one day. The transition from the United States, a bright world, is put into juxtaposition with Iran, a very dark one. Actually this darkness is felt in many details in the film. The Iranian Revolution, which took place in 1979 , is in the background of the film whose incidents happened between 1982 and 1984. Therefore, the political situation hovers over the film. A sense of guilt, as the film tries to evoke has been irritating Iranians abroad; so they want to return to Iran after the Revolution. Treated as a second class person in the United States, Moody deems it suitable to go back home.

"Not Without My Daughter" provides an interesting look at perceptions of the "other." In this film we see a character, Moudy, who although initially appears to be one of "us" turns out to be the "other". Moody's character is not well written since it shows severe contradictory behaviour: from a kind-hearted doctor to a violent Iranian just because he has returned home. Moreover the couple's relationship is not convincing. They have been happily married for seven years, however, moving to Iran has fostered a sense of estrangement in their relationship. The fact that 
the film is based on a true story does not mean that it presents the whole truth. There is exaggeration in the image of the Middle East and Islâm. The film is full of Islâm-related violence scenes which clearly illustrate a negative image of Muslims, if compared to the only three non-violent ones in the United States. Actually the folm presents a deformed image of the Islamic Revolution in Iran, which induced a close connection between Islâm and violence.

Betty the American wife is depicted as a victim to Muslim laws. She is not only forced to wear chador but she is also going to be killed by militant Islamists because she happens to wear a scarf. When she appeals to the court to go back home, she is depressed to find out that she can not leave because, according the Iranian law, she is Iranian. The film is a real conspiracy against Islâm. Muslims are seen as cheats, narrow-minded fanatics and sex maniacs. When Betty discusses the fact that her husband does not keep his promise as he has sworn to her not spend more than two weeks in Iran, all Muslims shout at her. Moreover, the attempt by a Muslim to rape Betty while asleep highlights the supposed savage nature of Muslims. In addition to the above-mentioned reasons, the physical beating of Betty is an important reason for her decision to leave.

Viewed from a feminist perspective, the film presents a distorted image of the woman. Though females are asked to cover themselves after puberty, Betty's daughter Medhab who is barley six is seen to follow the adults' example. However, the act of covering a six-year-old daughter the same way as an adult would when leaving the house, explains constructed realities as well as societal and familial values of Iranians. They express their own vision and interpretation of Islâm, which sometimes differ from the Qurân and Prophet Muhammad's Ahadiths, words and actions.

"True Lies" (1994) revolves around Harry Tasker, Arnold Schwarzenegger, the secret agent who works for the top secret Omega Sector, who must disarm the weapons: Soviet-made nuclear missiles in several U.S cities, which are to be detonated by members of an Arabic terrorist faction, known as the Crimson Jilad, if their extortionist demands are not met. The film shows anti-Islamic sentiments fervently propagated to dehumanize the Arabs:

There is now, for example, a new wave of large-scale feature films (one of them, True Lies, Karabell reminds us, "had as its villains classic Arab terrorists, complete with glinty eyes and apassionate desire to kill Americans") whose main purpose is to first demonize and 
dehumanize Muslims in order, second, to show an intrepid Western, usually American, hero killing them off.(Said. Covering Islam. xxvi-vii)

Truly, Arabs are negatively and stereotypically portrayed. The misbehaving abu-Aziz is put in juxtaposition with the decent Tasker who apologizes to everyone while chasing his Arab target. Furthermore:

The Arab characters within Crimson Jihad
themselves also had negative images... One
member of the terrorist group, named Samir,
was portrayed as a torture specialist. The
character's lines and actions were strikingly
similar to the characters of Nazi scientists
portrayed in World War II movies-one-
dimensional evil. Samir had a sizable cache of
"tools that he presumably used to pry
infuimation out of his captives." (However, in
"True Lies" Samir was never able to display his
"talents.") (Simon)

To make matters worse, "True Lies" not only uses Arabs to play many Arab roles, but it also uses the Arabic language when Arabic is supposedly to be spoken.

Besides advocating anti-Arab sentiment, the film succeeds in deepening suspect, mistrust and degradation of Arabs:

Further, during headquarters briefings, the chief of the Omega Sector (Charleton Heston) concludes, "Perhaps you better get some [solid evidence] before somebody parks an automobile in front of the White House with a nuclear weapon in the trunk." The film was made before the 1995 Oklahoma City bombing, and the premature release by news agencies of speculation that the bombers were "Middle Eastern-looking" males. In the aftermath of Oklahoma City, nevertheless, such a comment is very derogatory toward Arabs in generalregardless of the fact that during the Gulf War the United States made common cause with Saudi Arabia and Kuwait, even while 
demonizing Irac (and a decade and a half earlior, îran). (Simon)

The complexily of the Arab-American relations lies in the latter's propagandist effort to disfigure the former while, at the same time, playing a complicated role of a provocaleur and organizer.

The situation in America and Hollywood is far more complicated. People's viewpoints are not only biased, but they are also politically governed. Therefore, the Arabs, who are unjustly made a substitute for the Soviet Union and who are the Jews pet aversion, are doomed to be hated and negatively portrayed:

As True Lies has shown, Hollywood is far from changing it traditional outhook on the Arab world in its violent action films. At a fundraiser, Republican Party presidential candidate Senator Robert Dole placed 'I'rue Lies on his list of movies that are "friendly to families" (Weinraub 1). Bob Dole allacked such movies as Natural Born Killers and I'rue Romance for their use of unnecessary violence to sell tickets, yet regarded I'rue Lies as a film which promoted patriotism and family values. While this classification may seem absurd, it might be explained by the fact that Senator Dole has never seen the film, and that Arnold Schwarzenegger, the movie's `star, is a staunch Republican who supports Dole's candidacy. (Simon)

The same negative stereotypes are found in Aladdin. Aladdin is a street-urchin who lives in a large and busy town long ago with his faithful monkey friend Abu. When Princess Jasmine gets tired of being forced to remain in the palace that overlooks the city, she sneaks out to the marketplace, where she accidentally meets Aladdin. Under the orders of the evil Jafar (the sultan's advisor), Aladdin is thrown in jail and becomes caught up in Jafar's plot to rule the land with the aid of a mysterious lamp. Legend has it that only a person who is a "diamond in the rough" can retrieve the lamp from the Cave of Wonders. Aladdin might fight that description, but that's not enough to marry the princess, who must (by law) marry a prince. shows 
negative stereotypical imagery and lyrics. Offensive speech shows itself in the opening song "Arabian Nights"

"Oh, I come from a land From a faraway place Where the caravan camels roam. Where they cut off your ear If they don't like your face It's barbaric, but hey, it's home." (Scripps)

Of course the lines depict a negative image of a land of savages and uncivilized Arabs. As a result, the American-Arab Anti-Discrimination Committee protested and only the fourth and fifth lines changed into

"Where it's flat and immense And the heat is intense". (Scripps)

The sixth line, which remained as it is, stresses the stereotypical image of the savage.

The film portrays Arabs as street rats. Jafar, the Sultan's grand vizier, and Kazim, the thief who will get the magic lamp for Jafar, are depicted with a scatter-haired beard and a fake heavy accent. However, the three main characters, Aladdin, Jasmine and the Sultan, are given good qualities:

The Sultan is portrayed as being little more than a jolly old man who unknowingly is abused by Jafar. Aladdin is a misunderstood street beggar who is only doing the things he needs to do to survive, yet he still has a heart and a sense of charity-he is shown in an early scene giving two children a loaf of bread whose theft was the reason he spent the previous scene running away from the palace guards. Princess Jasmine is portrayed as a sweet woman whose only desire is to experience life for herself, outside of the palace walls. Compared to the violence and crime that is shown to exist in the streets and among the other characters, these three characters cast a stark contrast to most of what Disney portrays as Arabia. (Simon)

In their lengthy article entitled "Islam, Animation and Money: the Reception of Disney's Aladdin in Southeast Asia", White and Winn disapprove of the way Muslims in Malaysia see "Aladdin" as offensive and racist. They try to belittle the dehumanizing effect of the opening song: 
In fact, only one of the major Malaysian newspapers covered the story, and that paper was an English-language newspaper; none of the major Malay-language newspapers reported ABIM's (Angkatan Belia Islam) call. The only review of the film to appear in a major Malaysian newspaper failed to incention the controversy, and not only did the reviewer not complain about racism, she was entircly enthusiastic about the film, encouraging adults as well as children to see it. (White and Wimn)

It seems that American entertainment media likes to show, in movies and television programs, a distorted image of Arabs as a nationality and an ethnic group. The use of the language stresses the negative image since good characters speak perfect English while bad ones do not:

Some critics have argued that a film that stereotyped African-Americans or Jews as "Aladdin" did Arabs never would have been released. And, as an Arab-American critic of the film pointed out, although Jasmine and Aladdin are positive Arab characters, they speak American English, as opposed to the heavily-accented English of the evil characters in fact, the character of Aladdin was modelled on the American actor Tom Cruise. (White and Winn)

They tried to account for the supposed insensitivity of Malays under the pretext that they are not Arabs. Moreover they argued that being Muslims who are used to bloody scenes of amputations in their movies, makes it natural for them to see less supposedly savage scenes:

In other words, in most respects it is an animated version of the typical Malay movie. And the depictions of Islamic law in the filmfor example the threatened punishment of the amputation of Jasmine's hand for inadvertently stealing an apple, or the beheading (that didn't actually occur) of Aladdin for stealing a loaf of 
bread (or for consorting with the princess Jasmine; it never is made quite clear)- is rather tame compared to the punishments meted out in many Malaysian period films, in which characters routinely suffer amputations of various body parts, or are speared, beheaded, and/or burned alive, all in the name of Allah. Anyone familiar with Malaysian cinema should have no problem understanding why audiences, in general, chose to ignore calls to ban or boycott the film and instead treated themselves to an evening of song and romance. (White and Winn)

The above quotation implies a stereotypical image of a savage people who are to dismember each other at the slightest mistake as illustrated in the scenes of violence.

However and for all that is said, the fact remains that the images of Arabs are still as negative and distorted as they were long
ago:

Even in this age of "political correctness," Hollywood has been either unable or unwilling to change its representation of Arabs and the Middle East. Arabs todayas they were more than 70 years ago-are portrayed as being bandits, terrorists, thieves, and beggars. While Hollywood has taken some amelioration, the casting of Arabs themselves to play demeaning roles is not enough. The work of groups like the American-Arab Anti-Discrimination Committee has created a new awareness that there are problems that need to be addressed. Perhaps, if Hollywood takes this advice, then film audiences may begin to know the true lifestyle and culture of the modern Arab. (Simon) 
Since Islâm is misrepresented through a limited perspective where its nonconformity to the patterns designed by Western thinkers is stressed, the only way to depict a true and unbiased image of Islâm and Arabs is to view them through a multi-dimensional perspective. To this effect, Said, in Covering Islam, quotes the distinguished Algerian scholar and critic Mulhammad Arkoun, Sorbonne Professor of Islanic Thought:

The academic discourse on "Islamic studies" las still to proffer expianation as to how so many diverse fields, theories, cultural spheres, disciplines, and concepts came with a single word "Islam" and why the discussion remains so one-dimensional where Islan is concerned. In contrast, the study of Westem society is chavacterized by careful scrutiny, attention to precise detail, meticulous distinctions, and theory-building. Indeed, the study of West- en cultures continues to develop along such lines and to move in a different direction altogether from the unfortate approach adopted in the area of "Islam" and the socalled "Arab world." (Quoted by Malise Ruthven, LondonReview of Books, August 1, 1996, p.27) (171)

As Arkoun's argument shows, the only possible solution to such misrepresentation is to hold unprejudiced criteria when studying Isâlın and to scrutinize every minute detail meticulously so that one can pass a true judgment, not just mere groundless generalizations 


\section{Works Cited}

-Al Ashqar, Amr Soliman. The Woman Between Callers for Islam and Pretenders of Progress. Amman: Dar Al Nafae's, 1991.

-Ansari, M. H. "Thwarted dreams" India's National Magazine. Vol. 15: No. 21: Oct. $10-23,1998$. Monday 23 ${ }^{\text {rd }}$, Feb. Available on hllp://www. flomet.com.

- Pipes, Daniel and Durán, Khalid. "Muslims in the West: Can Conflict $\mathrm{Be}$

Averted?" United States Institute of Peace: August 1993. 21 Jan., 2004. Available on $\quad \underline{h t t p: / / w w w . d a n i e l p i p e s . o r g / a r t / c a t / 14}$. - Quryshi, Omar Ibn Abd AL Aziz. Do Justice to the Woman (or Injustice Done

to the Muslim Woman Between Reality and Condemnation)

Cairo: Hannon Press, n.d.

-SAID, EDWARD W. " A Devil Theory of Islam" The Nation.( July 25, 2000) Feb,2004. Available

https://ssl.thenation.com/sumo/articlelink75cent

Covering Islain.(1981) USA: Vintage Books, 1997.

- Scripps, Ben. "Aladdin Script". The Walt Disney Company, 1992. $25^{\text {th }}$ Feb.

2004. Available onwww.corky.net/scripts/aladdlin.html

- Simon, Scott J. "Arabs in Hollywood: An Undeserved Image" Northeastern

University. $3^{\text {rd }}$ Jan., 2004. Available on

http://altweb.emerson.edu/organizations/fas/latent_image/index.htm

- Sindi, Abdullah Mohammad. "The Jewish Grip on American Film and

Television Promotes Bias Against Arabs". $5^{\text {th }}$ march, 2004. Available on http://www.theunjustmedia.com/

- WEIJIAN, LI. "CULTURAL FACTORS IN ARAB-WEST RELATIONS" $1^{\text {st }} \quad$ March, 2004. Available on

www.crvp.org/book/Series20/cloapter ix.htm

- White, Timothy R. and Winn, J. E. "Islam, Animation and Money: the 
Reception of Disney's Aladdin in Southeast Asia" $12^{\text {th }}$ Feb, 2004.

Available

on

http://www.arts.uwaterloo.ca/FINE/julıde/index.hun 


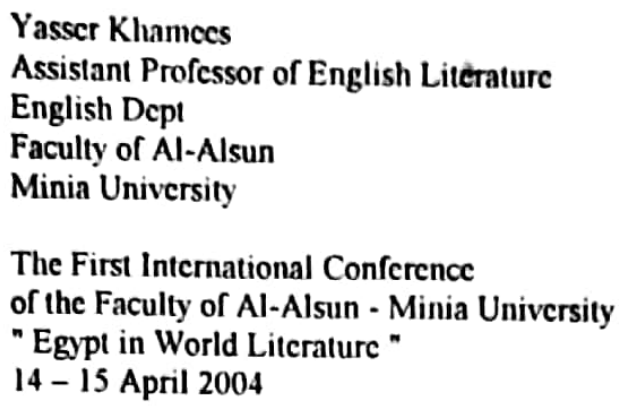

\section{Abstract \\ The \\ Misrepresentation of Arabs in the Western Media}

The sterentypical image of Arabs is the creation of a biased opinion or view. Arabs are currently seen as terrorists and murderers according to the Western media. Mistrust and abhorrence have become American common feeling towards the distorted image of Arabs. The unconscious wish not to separate stereotypes from reality governs every aspect of Arab-Western relations. Arab movie stereotypes are wealthy, barbarians, uncultured, sex maniacs, terrorist and religious fanatics as in films such as Not Without My Daughter and True Lies. They are depicted as greedy who uses oil, a natural and indispensable resource, to satisfy their hunger for money. The word terrorism has become synonymous with Arabs. In 1995 the Oklahoma City bombing was announced to be an act of terrorism done by Arabs, for which an inexplicable indictment $\mathrm{CNN}$ had provided names of Arab suspects even before facts were confirmed. However, and to the American society's disappointment, it was an American citizen who had done it. How long is long enough for such a misrepresentation to be changed? 


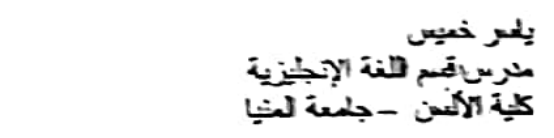

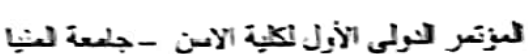

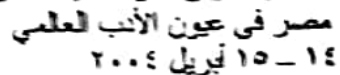

\section{ملخص}

\section{موء تقَيم المرب فى وبنال الأعلام الغزبية}

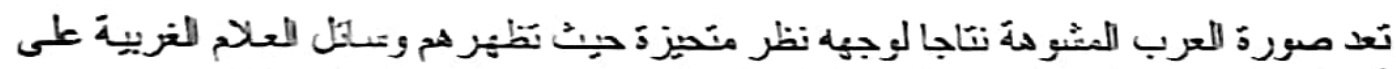

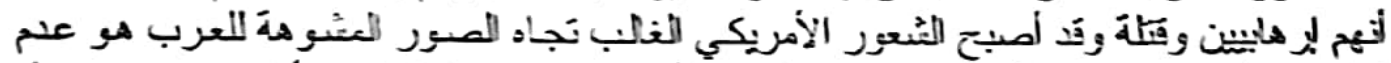

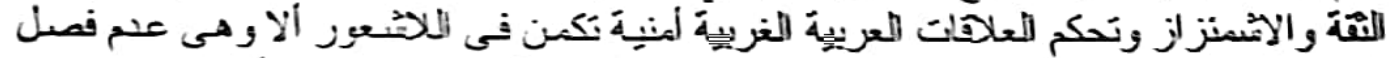

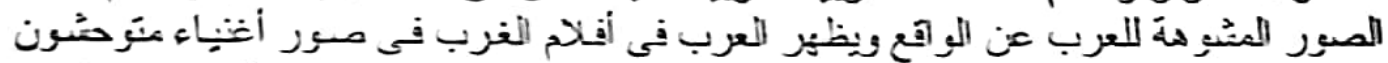

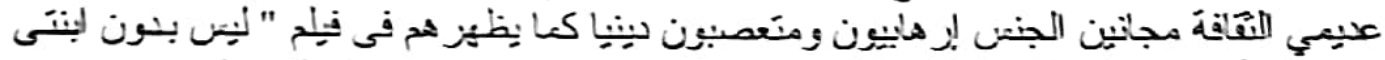

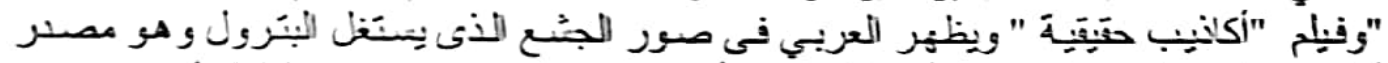

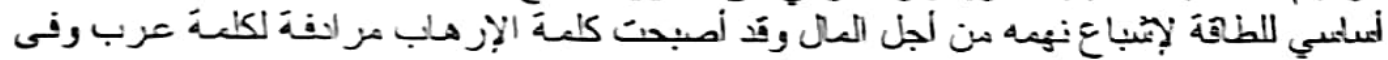

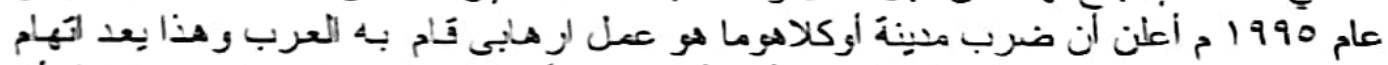

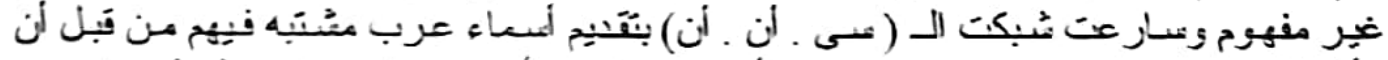

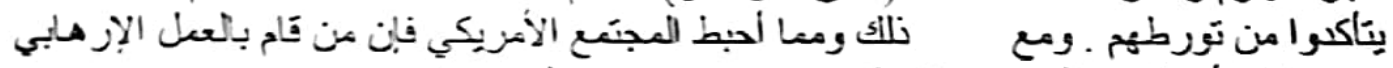

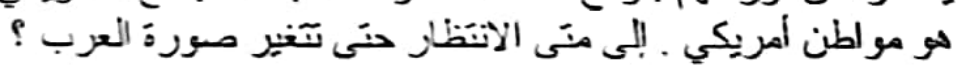

